\title{
Peter Guráň
}

\section{Trnavska Univerzita w Trnavie}

\author{
Lucjan Miś @ic https://orcid.org/0000-0002-6845-4565
}

\author{
Uniwerstytet Jagielloński w Krakowie
}

\section{RODZINA I POLITYKA RODZINNA W POLSCE I NA SŁOWACJI}

\begin{abstract}
The family and family policy in Poland and Slovakia

According the research the family is the highest value in the Poles and the Slovaks. The surveys show that the opinions of Poles and Slovaks about the family are very similar. Nowadays the family policy is becoming one of the most key areas of social policy in the Central European countries. In Slovakia, family policy has been implemented consistently and generously for many years as a result of a multi-party agreement. In Poland, after many years of dismantling the welfare state, there has been a radical socio-political turn by initiating active pro-family policy.
\end{abstract}

Key words: family, policy, Poland, Slovakia

\section{Wprowadzenie}

Rodzina jest stałym przedmiotem badań socjologicznych. Jednym z powodów jest fakt, że stanowi ona podstawową grupę i instytucję społeczną, oraz to, że jej wielkość, skład, granice i charakter ulegają ciągłym zmianom. Współcześnie problematyka ta jest intensywnie obecna w teorii i praktyce ze względu na pojawienie się przeformułowań definicji rodziny i związane z tym konsekwencje polityczne. Chodzi o rozszerzenie uprawnionych do różnego rodzaju świadczeń społecznych (zasiłków, pomocy rzeczowej, usług) i określenie, kto może być klientem pomocy społecznej. Ustawodawca musi się posługiwać jakimiś kryteriami zaliczania różnych konfiguracji interpersonalnych do kategorii „rodziny”, a następnie włączać i wyłączać pewne z nich z pomocy oferowanej przez państwo.

Najnowsze badania polskie pokazują pierwszoplanowe znaczenie rodziny w systemie wartości Polaków. Rafał Boguszewski (2019: 1) stwierdza, że 
Szczęście rodzinne zajmuje niezmiennie pierwsze miejsce wśród najważniejszych wartości, jakimi Polacy kierują się w swoim codziennym życiu. W styczniowym badaniu [2019 rok - przypis L.M.] wskazało na nie w tym kontekście aż cztery piąte spośród ogółu ankietowanych (80\%). Na drugiej pozycji, ze zdecydowanie mniejszą liczbą wskazań (55\%), znalazło się zdrowie, na trzecim - spokój (do najważniejszych wartości zaliczyło go 48\% respondentów), a na czwartym - grono przyjaciół (45\%). Mniej więcej dwie piąte Polaków za istotne w swoim życiu uznało szacunek innych ludzi (42\%) oraz uczciwe życie (42\%), a ponad jedna trzecia wskazała w tym kontekście na pracę zawodową (36\%). Nieco mniej liczni wymienili wiarę religijną (28\%), pomyślność ojczyzny (23\%) oraz wolność głoszenia własnych poglądów (18\%). Natomiast za stosunkowo najmniej ważne z perspektywy codziennej egzystencji badani uznali: dobrobyt i bogactwo (9\%), udział w demokratycznym życiu społeczno-politycznym (8\%), życie pełne przygód i wrażeń (5\%) oraz sukces i sławę (3\%).

Ze względu na wartość przypisywaną rodzinie przez społeczeństwo rodzina pozostaje przedmiotem działań politycznych. Władze decydują o ułatwianiu lub utrudnianiu rozwodów, wspieraniu lub zniechęcaniu do samotnego macierzyństwa, polityce pronatalistycznej lub kontroli urodzin itd. Spektakularnym aktem politycznym w ostatnich czterech latach w Polsce okazało się opracowanie i wprowadzenie w 2016 roku programu Rodzina 500+ (z jego różnymi rozwinięciami). Zmiany podatków czy nowa polityka przemysłowa, które zazwyczaj były w centrum uwagi partii politycznych i opinii publicznej, nie odegrały w tym przypadku porównywalnej roli do nowej polityki bezpośredniego dofinansowania dzieci w rodzinie. Okazało się, że tego typu działania spowodowały szczególną rewolucję świadomościową i głęboką zmianę polityczną. Co więcej, program 500+ wywarł wpływ na zmianę retoryki, a czasami również zmianę polityki społecznej w innych krajach (na przykład propozycje Ivanki Trump w USA dotyczące wsparcia rodzin i bezpośrednie dofinansowanie rodzin przez rząd rosyjski po wprowadzeniu programu Rodzina 500+ w Polsce).

\section{Rodzina i dzieci w Polsce i na Słowacji}

Z jednej strony mieliśmy i mamy deklaracje o wartości i ważności rodziny, z drugiej spadek liczby urodzeń i kryzys dzietności. Należy pamiętać, że deklaracje te bezpośrednio odnoszą się do współczesnego modelu rodziny, a więc rodziny małej: z jednym lub dwójką dzieci. Porównawcze badania nad aktualną i pożądaną wielkością rodziny pochodzą sprzed lat (Svarc, Svarcova 2007). Są one jednak jedynym dostępnym źródłem wiedzy na ten temat.

Przedstawione poniżej na wykresach dane dotyczące aktualnej wielkości rodziny, planów na przyszłość i pożądanej liczby dzieci w rodzinie pokazują, że Polacy i Słowacy mieli bardzo podobne opinie na ten temat. Większość z nich deklaruje, że odpowiada im model z dwójką dzieci, czyli model, który nie zapewnia reprodukcji prostej i wzrostu populacji (zob. wykresy 1-5). 


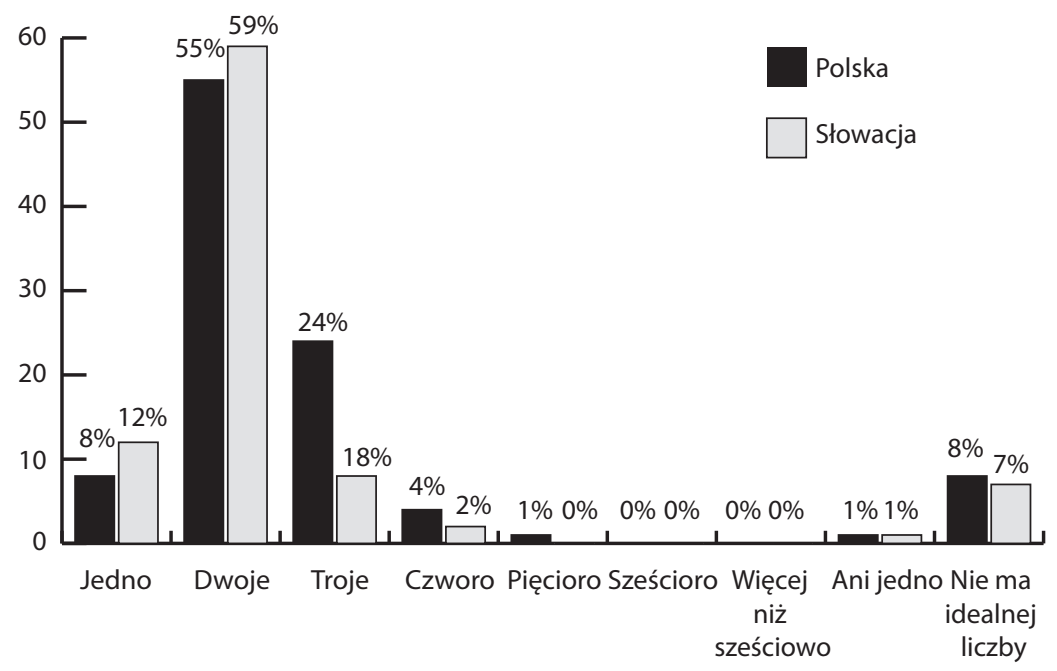

Wykres 1. Odpowiedzi na pytanie „Ogólnie rzecz biorąc, jaka jest Pana(i) zdaniem idealna liczba dzieci w rodzinie?” (w \%) w Polsce i na Słowacji

Źródło: Opracowanie własne.

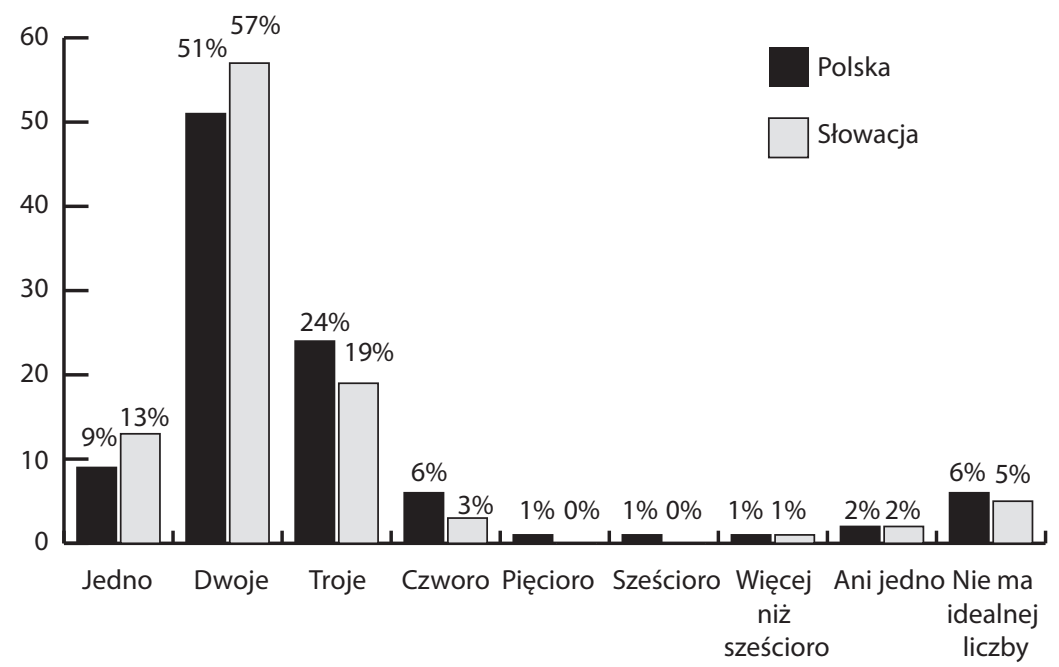

Wykres 2. Odpowiedzi na pytanie: „A dla Pana(i) osobiście jaka byłaby idealna liczba dzieci, jakie chciał(a)by Pan(i) mieć, również gdyby można było cofnąć czas?” (w \%) w Polsce i na Słowacji Źródło: Opracowanie własne. 


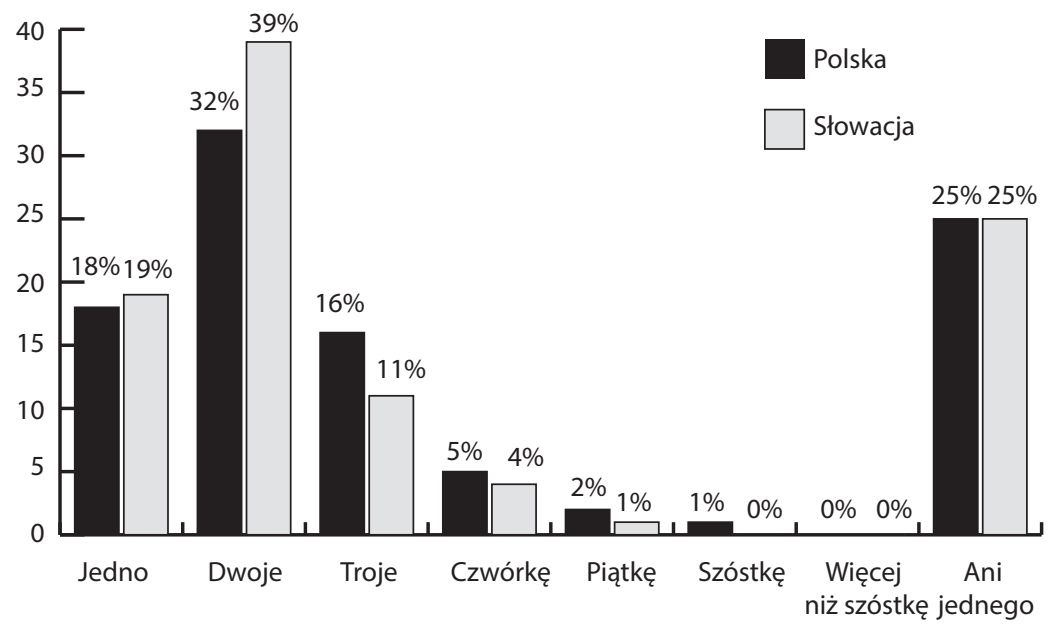

Wykres 3. Odpowiedzi na pytanie: „Ile dzieci, jeśli w ogóle, Pan(i) miał(a)?” (w \%) w Polsce i na Słowacji

Źródło: Opracowanie własne.

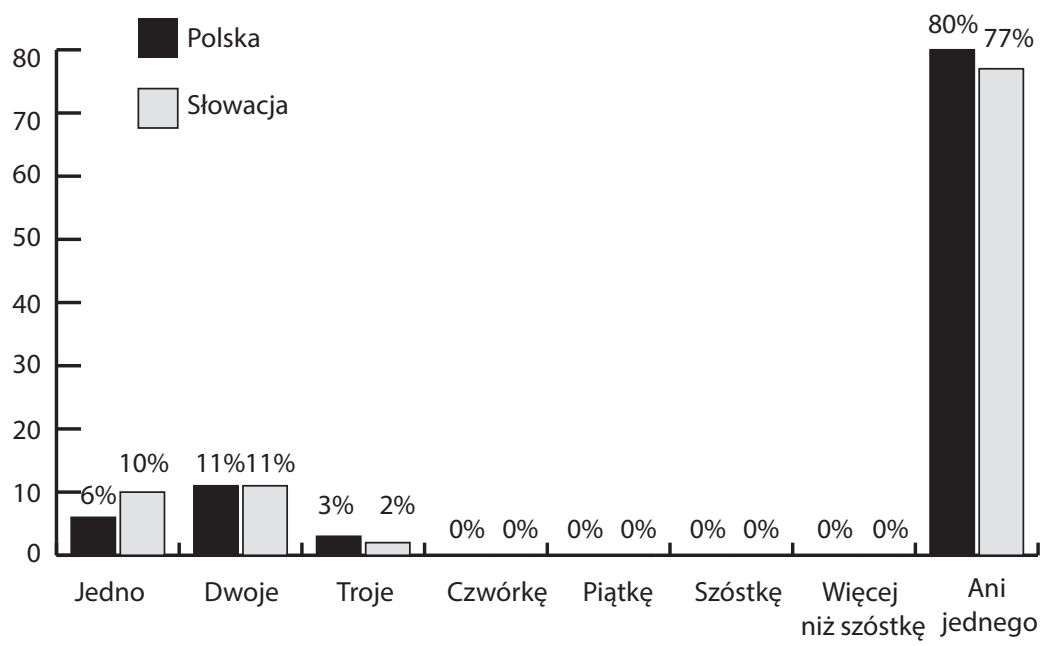

Wykres 4. Odpowiedzi na pytanie: „Ile dzieci zamierza Pan(i) (jeszcze) mieć?” (w \%) w Polsce i na Słowacji

Źródło: Opracowanie własne. 


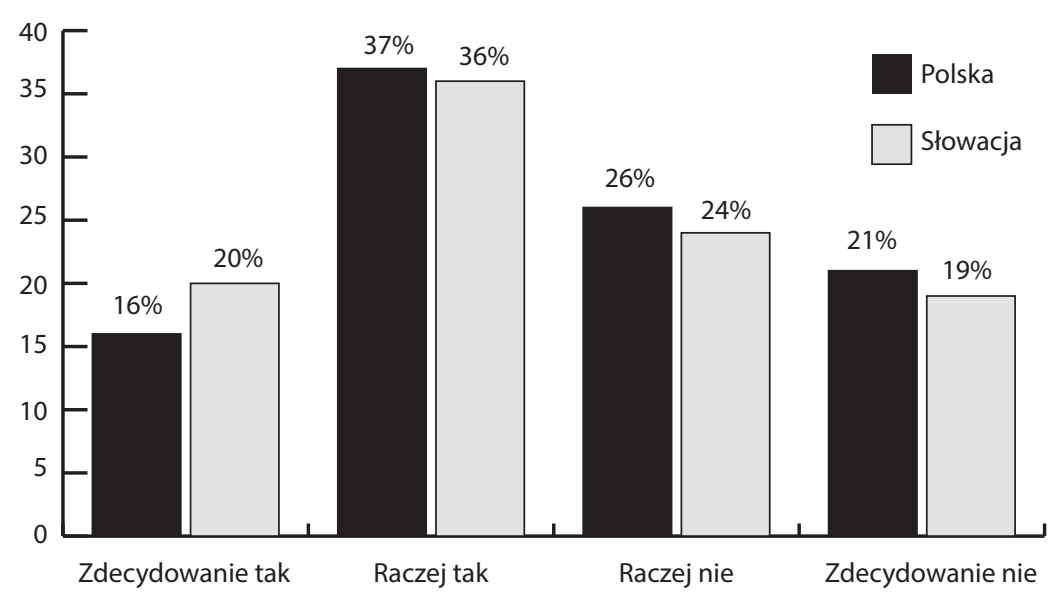

Wykres 5. Odpowiedzi na pytanie: „Czy zamierza Pan(i) mieć (następne) dziecko w ciągu najbliższych 3 lat?" (w \%) w Polsce i na Słowacji

źródło: Opracowanie własne.

\section{Polityka rodzinna w Polsce}

Polska jest przykładem kraju, w którym polityka rodzinna stała się szczególnego rodzaju mechanizmem spustowym przemian politycznych. Program Rodzina 500+ odegrał ważną rolę w kampanii wyborczej, a następnie stał się elementem zmiany areny politycznej. Lata 2015 i 2016 okazały się przełomowe dla polityki społecznej, ale również dla polityki gospodarczej i fiskalnej w Polsce.

Model polityki społecznej w Polsce przed 2016 rokiem został określony jako paternalistyczno-rynkowa hybryda. Główna uwaga prawodawcy skupiała się na rodzinach o niskich dochodach i na wspieraniu ich przez różnego rodzaju świadczenia. Miały one selektywny i osłonowy charakter, a były realizowane głównie przez zasiłki lub pieniężną pomoc innego rodzaju.

Polityka rodzinna państwa polskiego ewoluowała. Za najważniejsze zmiany uznawano (Firlit-Fesnak 2018):

- wydłużenie wymiaru urlopu macierzyńskiego;

- ustanowienie nowego rodzaju urlopu - dla ojców;

- wprowadzenie pieczy zastępczej.

Wprowadzenie tych zmian odbywało się $\mathrm{w}$ warunkach konsensusu politycznego w zakresie poszerzenia praw matek i dzieci. Konfliktowe były kwestie związane z ustanowieniem nowego rodzaju urlopu dla ojców, który przez środowiska feministyczne i lewicowe został nazwany urlopem „tacierzyńskim”. W środowiskach tradycjonalistycznych i prawicowych urlop ten określano jako ojcowski. Istotny spór polityczno-społeczny 
powstał przy okazji uchwalenia i podpisania ustawy o przeciwdziałaniu przemocy domowej. Podpisanie tej ustawy przez prezydenta Bronisława Komorowskiego odbyło się w gorącym okresie prezydenckiej kampanii wyborczej. Spotkało się z entuzjazmem środowisk liberalnych i krytyką ze strony partii konserwatywnych oraz środowisk związanych z Kościołem rzymskokatolickim.

Zmiany w polityce społecznej po 2015 roku miały wybitnie prorodzinny charakter. Współcześnie pakiet programów socjalnych skierowanych do rodziny obejmuje:

- Program Rodzina 500+;

- Program Dobry Start (rodzaj „wyprawki szkolnej”, czyli 300 złotych wsparcia dla dzieci rozpoczynających rok szkolny);

- Program Maluch+ (rozwój różnych form opieki dla najmniejszych dzieci do 3. roku życia).

Utrwaleniu i poszerzeniu uległy programy i świadczenia, które zostały wprowadzone w latach wcześniejszych. Chodzi tu o:

- Kartę Dużej Rodziny;

- świadczenia rodzinne, czyli zasiłki i dodatki do zasiłku rodzinnego (opiekuńcze, związane z urodzeniem dziecka itp.);

- fundusz alimentacyjny;

- wsparcie rodziny przeżywającej trudności opiekuńczo-wychowawcze;

- opiekę zastępczą nad dzieckiem;

- usamodzielnie młodzieży opuszczającej instytucje opiekuńczo-wychowawcze.

Ustanowienie nowych programów i wprowadzenie ich w życie nie pozwala na sformułowanie konkluzji na temat ich planowanych i niezaplanowanych skutków dla rodziny i społeczeństwa. Natomiast w opinii specjalisty ogólna opinia o polityce rodzinnej w okresie ostatnich trzydziestu lat nie jest pozytywna: „Bilans polityki rodzinnej w Polsce po 1989 roku nie wypada korzystnie" (Firlit-Fesnak 2018: 230).

\section{Rodzina i polityka na Słowacji}

Rodzina jest również najważniejszą wartością w społeczeństwie słowackiem. Potwierdzają to badania sprzed 1989 roku oraz współczesne. W hierarchii wartości rodzina zawsze ma najwyższą rangę dla ponad 80\% respondentów, niezależnie od ich cech demograficznych i społecznych. Ten szczególny status rodziny odzwierciedla się również na poziomie polityczno-społecznym. W 1996 roku, wkrótce po odzyskaniu niepodległości przez Słowację, rząd Republiki Słowackiej przyjął strategiczny plan - koncepcję państwowej polityki rodzinnej rozumianą jako rezultat pewnego społecznego konsensusu co do roli państwa wobec rodziny. Stworzono nową filozofię metod i środków polityki rodzinnej państwa zapewniającą ciągłość pomocy, lecz nie poprzez bezpośrednią interwencję i wpływanie na rodziny przez państwo, jak to było w przeszłości. Rodzina została zdefiniowana jako podstawowe środowisko dla osobistego rozwoju każdej jednostki oraz jako fundamentalna grupa społeczna. Zdefiniowano również 
nowy status rodziny w społeczeństwie demokratycznym: przez wdrożenie zasady pomocniczości, uznanie praw dzieci, kobiet i innych praw człowieka oraz przeciwdziałanie dyskryminacji.

Główne cele polityki rodzinnej państwa można krótko scharakteryzować w następujący sposób:

- równowaga między życiem zawodowym i rodzinnym;

- zwalczanie wykluczenia społecznego i ubóstwa rodzin z dziećmi;

- promowanie solidarności i opieki międzypokoleniowej;

- elastyczne reagowanie na negatywne trendy demograficzne, zwłaszcza spadek liczby urodzeń;

- wdrażanie konwencji międzynarodowych, w szczególności Konwencji Organizacji Narodów Zjednoczonych o prawach dziecka (CRC), Konwencji w sprawie likwidacji wszelkich form dyskryminacji kobiet (CEDAW), a także rozporządzeń Rady Europy i zaleceń w tej dziedzinie.

Cele te są wprowadzane stopniowo w ramy prawne Republiki Słowackiej dotyczące rodziny. Podstawowe ustawy w tym zakresie to: ustawa o rodzinie (2005) oraz ustawa o społecznej i prawnej ochronie dzieci i o kuratorze społecznym (2005).

Wszystkie kolejne poprawki uwzględniają zalecenia ONZ i RE (CE) (na przykład najlepsze interesy dziecka, prawa kobiet, zalecenia społeczne dotyczące rodzin romskich, równoległy urlop rodzicielski itp.).

W niektórych dziedzinach nie osiągnięto jednak konsensusu społecznego i wystarczającej woli politycznej. Dotyczy do ratyfikacji konwencji stambulskiej (Konwencji o zapobieganiu i zwalczaniu przemocy wobec kobiet i przemocy domowej) z 2011 roku.

\section{Bezpośrednie i pośrednie środki polityki rodzinnej państwa}

Cały system polityki rodzinnej państwa można podzielić na środki bezpośrednie i pośrednie. W przeszłości przeważały środki bezpośrednie. Stworzono dość skomplikowany system wielu transferów finansowych, który był nieprzejrzysty i biurokratyczny. Obecna tendencja polega na wzmocnieniu pośrednich środków polityki rodzinnej, zwłaszcza $\mathrm{w}$ dziedzinie usług i zapobiegania niekorzystnym zjawiskom w rodzinie.

\section{Bezpośrednie świadczenia polityki rodzinnej państwa}

Zasiłek na dziecko jest najbardziej rozpowszechnionym bezpośrednim świadczeniem państwowym. Jest to świadczenie zwolnione z testu dochodowego i wszystkie dzieci mieszkające na Słowacji mają do niego prawo. Limit wiekowy to 18. rok życia, dla studentów kontynuujących naukę na dowolnym uniwersytecie zaślimit wiekowy dla zasiłku na dziecko wynosi 26 lat. Co ciekawe, zasiłek na dziecko składa się z części bezpośredniej (25 euro miesięcznie) oraz ulgi podatkowej (22 euro miesięcznie), która ma funkcję motywacyjną dla przynajmniej jednego z rodziców, który stale pracuje. 
Innym typowym świadczeniem finansowym jest zasiłek porodowy. Wszystkie matki, które urodziły dziecko na Słowacji, mają do niego prawo (do czwartego tygodnia po urodzeniu dziacka). Świadczenie to jest uzależnione od liczby dzieci w rodzinie. Od pierwszego do trzeciego dziecka zasiłek wynosi 830 euro. W przypadku większej liczby dzieci kwota zostaje obniżona do 151 euro.

Zasiłek rodzicielski to dodatek, który pozwala rodzicom pozostać $\mathrm{z}$ dzieckiem $\mathrm{w}$ domu po zakończeniu urlopu przez matkę (28 tygodni po urodzeniu dziecka). Zasiłek rodzicielski może być wykorzystany przez trzy lata, a dla dziecka niepełnosprawnego przez sześć lat. Jego konstrukcja jest elastyczna - może być wykorzystywany zarówno przez matki, jak i ojców, mogą oni wykonywać opiekę na zmianę i zrealizować to świadczenie w ciągu pięciu lat od urodzenia dziecka. Jego kwota wynosi 220 euro dla pierwszego i drugiego dziecka, dla pozostałych dzieci całkowita stawka jest zmniejszona o $25 \%$.

System bezpośrednich świadczeń państwowych uzupełniają różne dopłaty za narodziny bliźniąt, trojaczków, dziecka niepełnosprawnego itp.

Najbardziej rozpowszechnionym świadczeniem rodzinnym wypłacanym z systemu ubezpieczeniowego jest urlop macierzyński. Jego długość to łącznie 34 tygodnie, w tym 6 tygodni przed porodem i 28 tygodni po porodzie. Dla samotnych matek urlop ten jest wydłużony do 37 tygodni oraz 43 tygodni dla matek bliźniąt. Wysokość tego świadczenia jest równa $70 \%$ wynagrodzenia brutto w poprzednim okresie, co odpowiada mniej więcej $100 \%$ poprzedniej płacy netto.

Świadczeniem rodzinnym wypłacanym również z systemu ubezpieczenia społecznego jest świadczenie dla najmłodszych dzieci lub innych członków rodziny (pokrycie kosztów leczenia). Jego długość wynosi od 1 do 10 dni i obejmuje 55\% dochodu.

Inne korzyści finansowe dla rodziny nie są gwarantowane przez państwo, ale są związane z regionem lub niektórymi instytucjami, na przykład stypendia dla studentów, pożyczki itd.

\section{Pośrednie środki polityki rodzinnej}

Aktualnym trendem w tej dziedzinie jest wspieranie zmienności i elastyczności środków polityki rodzinnej. Podąża się za zmianami społecznymi polegającymi na różnicowaniu życia rodzinnego oraz przemianami form życia rodzinnego związanymi ze zwiększaniem udziału ojców w opiece nad dziećmi itd. Dąży się również do zatrzymania spadku przyrostu naturalnego i ustabilizowania go na podstawie doświadczeń z innych krajów.

Najbardziej znanym i rozpowszechnionym środkiem jest ulga podatkowa (taxbonus), która stanowi motywacyjną część zasiłku na dziecko, stopniowo waloryzowanego. Kwota tej ulgi wynosi 22 euro, a od kwietnia 2019 roku została podwojona ulga podatkowa dla rodzica dziecka do 6. roku życia (44 euro). Dotyczy to również innych środków mających na celu promowanie edukacji przedszkolnej w kontekście celów barcelońskich UE.

Kolejnym świadczeniem na rzecz rodziny są bezpłatne obiady dla dzieci w przedszkolu w ostatnim roku przed przejściem do szkoły podstawowej. Wcześniej ten środek 
istniał, ale było to świadczenie selektywne, tylko dla dzieci z rodzin żyjących poniżej minimum socjalnego (na podstawie testu dochodowego). Od stycznia 2019 roku wszystkie uprawnione dzieci mają możliwość korzystania z bezpłatnych obiadów. Podobnie od września 2019 roku rozpocznie się wydawanie bezpłatnego lunchu dla wszystkich dzieci w szkole podstawowej.

W czerwcu 2019 roku rząd słowacki przyjął ustawę o obowiązkowej edukacji przedszkolnej: rok przedszkola dla dzieci od 5. roku życia.

Kontrowersyjnym świadczeniem, wprowadzonym kilka lat temu, są bezpłatne bilety kolejowe dla wszystkich studentów na Słowacji. Celem było zmotywowanie młodych Słowaków do nauki na wyższym poziomie kształcenia, ale nie został on osiągnięty.

Istnieją również inne pośrednie środki wsparcia dla rodzin, zwłaszcza rodzin z niepełnosprawnym dzieckiem czy dla osób starszych zależnych od pomocy, lecz nie omawiamy ich tu ze względu na ograniczenia redakcyjne.

Duża część pośredniego i (częściowo) bezpośredniego wsparcia państwa dla rodzin dotyczy rodzin w kryzysie, dzieci odebranych rodzicom biologicznym i mieszkających w rodzinach zastępczych lub adopcyjnych. Dla nich została stworzona specjalna kategoria „młodych dorosłych” (w wieku od 18 do 26 lat), którzy otrzymali prawo do różnego rodzaju pomocy ze strony państwa.

Podsumowując, system silnej polityki rodzinnej okazał się uzasadniony na Słowacji. Zapewnił on pewną ciągłość środków, a także wyznaczył ogólną filozofię i strategię pomagania. Nie zapewnia jednak całkowitej ochrony przed populistycznymi żądaniami poszczególnych ministerstw czy urzędów. Jest to system otwarty, który wymaga profesjonalnego podejścia, wdrażania dobrych doświadczeń zagranicznych i zaleceń instytucji międzynarodowych. Jest on odpowiedni tylko dla rządu, który szeroko współpracuje z istniejącymi niezależnymi organizacjami (Słowacki Komitet do spraw Dzieci i Młodzieży przy Rządowej Radzie Praw Człowieka, Rzecznik Praw Obywatelskich) i organizacjami pozarządowymi.

\section{Zakończenie}

Polska i Słowacja należą do Unii Europejskiej i do Grupy Wyszehradzkiej. Adrian Moliński (2019: 110) stwierdza w odniesieniu do krajów V4, w tym Polski i Słowacji, że:

Państwa Grupy Wyszehradzkiej stoją przed ogromnym wyzwaniem, jak dostosować politykę ludnościową, pronatalistyczną strategię demograficzną do wyzwań, jakie niosą ze sobą problemy starzenia się społeczeństwa, spadającej liczby dzietności, zmiany w mentalność ludzi, którzy czasem w ogóle nie decydują się na powiększenie swojej rodziny.

Porównanie obu krajów pokazuje próby rozwiązań podejmowane w formie różnych ustaw i programów przez władze tych krajów. W odniesieniu do Polski widzimy: 
- zmienność w założeniach ideologicznych i radykalny zwrot po zmianie rządu w 2015 roku;

- odejście od neoliberalnego paradygmatu: osłonowy charakter świadczeń skierowanych do rodzin o niskich dochodach;

- przyznawanie i odbieranie (ograniczanie) świadczeń (ulga podatkowa na każde dziecko z 2009, od 2013 roku - dla najuboższych rodzin);

- zmienność w zakresie ulg podatkowych (dla małżonków, samotnych rodziców, ulg związanych w edukacją).

$\mathrm{Na}$ Słowacji polityka rodzinna ma znacznie bardziej strategiczny i konsekwentny charakter. Program został wypracowany na zasadzie wielopartyjnego konsensusu i jest realizowany od ponad dziesięciolecia. Bieżące interesy polityczne również oddziaływały i powodowały zmiany modelu, na przykład hojne świadczenia dla studentów (zwolnienie z opłat za podróże koleją) czy wprowadzenie posiłków dla wszystkich dzieci w szkole.

Rodzina pozostaje największą wartością dla Polaków i Słowaków. Dlatego jest tak istotna dla polityków, którzy chcą ją wykorzystać dla swoich celów. Skuteczna polityka rodzinna polega na koherencji między wartościami i ideałami społeczeństwa a polityką państwa, która wychodzi poza partyjne interesy i realizuje zadania sprzyjające poprawie warunków życia i bytu rodzin. Badania społeczne pozwalają rozpoznać wartości i potrzeby oraz monitorować i ewaluować bieżącą politykę społeczną.

\section{Bibliografia}

Boguszewski R. (2019). Rodzina - jej znaczenie i rozumienie. Komunikat z badań. Nr 22 (2019).

Centrum Badania Opinii Publicznej, Warszawa.

Firlit-Fesnak G. (2018). Rodziny polskie i polityka rodzinna - stan i kierunki przemian, w: G. Firlit-Fesnak, J. Męcina (red.), Polityka społeczna. Nowe wydanie. PWN, Warszawa.

Moliński A. (2019). Wplyw transformacji ustrojowej na sytuacje demograficzna Grupy Wyszehradzkiej 2019, w: Studia Europejskie. Studies in European Affairs, 2018, nr 2. Centrum Europejskie Uniwersytetu Warszawskiego, Warszawa: 97-112.

Svarc P., Svarcova N. (2007). The Impact of Social and Tax Policies on Families with Children: Comparative Study of the Czech Republic, Hungary, Poland and Slovakia. IES Working Papers, 2007, nr 28. Institute of Economic Studies, Faculty of Social Sciences, Charles University in Prague, Praga. 